\title{
Management of thoracolumbar injury classification and severity score of 4 (TLICS $=4)$ thoracolumbar vertebra fractures: Surgery versus conservative treatment
}

\author{
(1) Evren Karaali, M.D., ${ }^{1}$ (1) Osman Çiloğlu, M.D.,, ${ }^{10}$ Altuğ Duramaz, M.D., ${ }^{2}$ \\ (1) Aslıhan Kuşvuran Özkan, M.D., ${ }^{3}$ ๑ Timur Ekiz, M.D. ${ }^{4}$
}

\begin{abstract}
${ }^{1}$ Department of Orthopedics and Traumatology, Adana City Hospital, Adana-Turkey
${ }^{2}$ Department of Orthopedics and Traumatology, Bakırköy Dr. Sadi Konuk Training and Research Hospital, İstanbul-Turkey

${ }^{3}$ Department of Physical and Rehabilitation Medicine, Özülkü Medical Center, Adana-Turkey

${ }^{4}$ Department of Physical Therapy and Rehabilitation, İstanbul Gedik University Faculty of Health Sciences, İstanbul-Turkey
\end{abstract}

\begin{abstract}
BACKGROUND: This study aims to compare clinical and radiographic outcomes of surgical treatment and conservative treatment with bracing in neurologically intact patients with score 4 of TLICS thoracolumbar vertebra fractures.

METHODS: Patients with traumatic thoracolumbar junction fractures (TII-L2), the score of TLICS 4, and minimum 24-month follow-up were included in this study. Patients were divided into surgery and bracing groups. The groups were compared concerning clinical and demographical features, local kyphotic angles (LKA), vertebra height loss percentage (VHL), Oswestry Disability Index (ODI), Visual Analog Scale (VAS) and time to return to work.

RESULTS: There were 74 patients ( 71 males, 3 females) in the surgery group and 76 patients (58 males, 18 females) in the bracing group. Although the surgery group showed better improvement in VAS scores within six months postoperatively, no significant difference was observed at the $24^{\text {th }}$-month evaluation $(p<0.00 I$ and $p=0.270$, respectively). ODI, LKA and VHL were significantly lower in the surgery group $(p<0.001, p<0.001$ and $p<0.001$, respectively). In addition, return to work was significantly earlier in the surgery group $(p<0.001)$.
\end{abstract}

CONCLUSION: The findings obtained in this study suggest that the surgical treatment for TLICS 4 patients with thoracolumbar fractures has better clinical and radiographic outcomes than the bracing. Moreover, returning time to the work of patients is shortened with surgical treatment. The surgical treatment seems to be the first and the appropriate choice in the management of TLICS 4 thoracolumbar vertebral fractures.

Keywords: Clinical and radiological outcomes; spinal bracing; surgical treatment; thoracolumbar fractures; TLICS.

\section{INTRODUCTION}

Acute fractures of the thoracolumbar spine can be managed either nonoperatively or surgically according to the type of fracture and clinic status of the patients (e.g., fracture morphology, neurological deficits, and ligamentous integrity). ${ }^{[1]}$ Using an easy, accurate, and injury classification system is crucial to guide surgeons in decision making on which treatment is more suitable for better clinical outcomes. In this context, although there is no unique universally accepted classification by surgeons, the Thoracolumbar Injury Classification and Severity score (TLICS) has been widely used among surgeons. $[1,2]$ There is almost no debate on the surgical treatment of severe fractures with posterior ligamentous complex (PLC) disruption and neurological injury as a score of more than 4 in TLICS. Conservative approach is recommended for the

Cite this article as: Karaali E, Çiloğlu O, Duramaz A, Kuşvuran Özkan A, Ekiz T. Management of thoracolumbar injury classification and severity score of 4 (TLICS=4) thoracolumbar vertebra fractures: Surgery versus conservative treatment. Ulus Travma Acil Cerrahi Derg 2020;26:805-810.

Address for correspondence: Altuğ Duramaz, M.D.

Bakırköy Dr. Sadi Konuk Eğitim ve Araştırma Hastanesi, Ortopedi ve Travmatoloji Kliniği, ìstanbul, Turkey

Tel: +90 212 - 4147 7 7 I E-mail: altug.duramaz@yahoo.com

Ulus Travma Acil Cerrahi Derg 2020;26(5):805-810 DOI: 10.14744/tjtes.2020.30524 Submitted: 16.09.2019 Accepted: 28.03.2020 Online: 09.09.2020

Copyright 2020 Turkish Association of Trauma and Emergency Surgery 
scores of less than 4 in minor traumas. However, as for the treatment of TLICS score 4 vertebra fractures, treatment may be surgical or conservative depending on patient variables and choice of the surgeon. ${ }^{[3]}$

The outcomes of operative and non-operative treatments in TLICS 4 thoracolumbar vertebra fractures are conflicting. ${ }^{[4-6]}$ From this point of view, there is a need for further studies comparing clinical outcomes of surgical and non-surgical methods for TLICS 4 vertebra fractures. Therefore, the present study aims to determine whether surgery or initial conservative treatment with bracing has a better clinical outcome in neurologically intact patients with intermediate severity thoracolumbar junction traumatic fractures classified TLICS 4. The present study hypothesized that clinical and radiological outcomes would be better in the surgical group within six months, but that there would be no difference between the groups after two years of follow-up.

\section{MATERIALS AND METHODS}

\section{Study Design and Patients}

This study was conducted as a single-center, comparative, and retrospective cohort study. The patients who had been followed-up in our center due to the TLICS 4 vertebra fracture between 2013 to 2017 were reviewed retrospectively, after approval of the local ethics committee (IRB protocol ID: 2017/04-10). Inclusion criteria were traumatic thoracolumbar junction fractures (compression and burst) between TII -L2, the only score of TLICS 4, without any neurologic deficit, age at $\geq 18$ years, without previous surgery, within 24 hours of presentation and a minimum six months of the follow-up period. Exclusion criteria were: patients with a follow-up period of fewer than six months, pregnancy, having pathologic or osteoporotic fractures, previous history of spine surgery, and any missing data regarding the fracture.

\section{Treatment Methods}

Conservative treatment protocol comprised horizontal bed rest depending on pain, a standardized rehabilitation program to train trunk musculature, and compliance to wearing thoracolumbar orthosis for at least three months. Short-segment posterior stabilization and instrumentation were performed to all the patients who underwent surgery and they did not wear thoracolumbar orthosis neither postoperatively nor after discharged. Also, a rehabilitation program was given to strengthen the trunk muscles.

\section{Data Collection and Radiographic Evaluation}

Demographical data, such as age, gender, level of injury, AO fracture type and etiology of the trauma, were gathered. All patients had images of plain radiographs, computed tomography, magnetic resonance imaging at presentation, and two plain radiographs at every follow-up visit. Angular measurements were performed on lateral spine radiographs at the first admission, third month, sixth month and $24^{\text {th }}$ month. Local kyphosis (LKA) was measured as the angle from the superior end-plate to the inferior end-plate. The anterior and posterior vertebral body heights of the injured segment were measured. Normalized vertebral body height loss (VHL) was calculated as a percentage of the height loss normalized to the average of the vertebral bodies above and below the injured segment. ${ }^{[7]}$ Radiographic measurements were made by the same senior spinal surgeons who followed the patients.

\section{Outcome Measures}

The primary functional outcome measure was the Oswestry Disability Index (ODI). The ODI is a functional, disease-specific instrument comprising 10 questions on limitations in activities of daily living, caused by low back pain. Each question is scored 0 to 5 . The ODI score is multiplied by two to acquire the percentage. The total score ranges from 0 (best health state) to 100 (worst health state). The index was validated for the Turkish population. ${ }^{[8]}$

Secondary outcome measures included back pain Visual Analog Scale (VAS) score and time to return to work. Records of VAS score for back pain at pre-treatment, third month, sixth month and $24^{\text {th }}$ month were collected and compared between the groups. VAS is a well-known, validated instrument to let patients score their daily pain. We used a 0 to 10 scale as scored; $0=$ no pain and $10=$ unbearable pain. ${ }^{[9]}$ Time to return to work was determined from self-reported at the last follow-up time.

\section{Statistical Analyses}

The IBM Statistical Package for the Social Sciences 20.0 (SPSS) was used to analyze the data. After checking the normal distribution with Kolmogorov Smirnov test and histogram graphics, the descriptive data were given as mean, standard deviation, number or percentage. Between-group comparisons of numeric data were administered using the Student's t-test. Repeated evaluations were compared using the Repeated Measures. The Chi-Square test was used to compare categorical data between the groups. A p-value of 0.05 was set as the significance level. In the calculation of post hoc sample size (Power and Precision, Version 2.0; Biostat, Englewood, NJ, USA), the power of the study with 0.05 alpha value was found over $80 \%$. The standard effect size for quantitative data was set at $1.37 \%$ and the power of this study was $99 \%$.

\section{RESULTS}

Demographic characteristics of the patients are presented in Table I. There was no significant difference between the groups concerning mean age, level of injury, AO fracture type and extra-vertebral fracture $(p>0.05)$. However, the number of male patients, duration of hospitalization, and fall from the height were significantly higher in the surgery group 
Table I. Demographic features of the patients in both groups

\begin{tabular}{|c|c|c|c|}
\hline & Surgery & Brace & $\mathbf{p}$ \\
\hline Age (years), mean $\pm S D$ & $49.64 \pm 18.5$ & $49.49 \pm 20.6$ & 0.963 \\
\hline Hospitalization (days), mean $\pm S D$ & $3.18 \pm 1.74$ & $1.50 \pm 0.6$ & $<0.001$ \\
\hline \multicolumn{4}{|l|}{ Gender, n (\%) } \\
\hline Male & 71 (95.9) & $58(76.3)$ & 0.001 \\
\hline Female & $3(4.1)$ & $18(23.7)$ & \\
\hline \multicolumn{4}{|l|}{ Level of injury, $n$ (\%) } \\
\hline TII & $9(12.2)$ & $5(6.6)$ & 0.295 \\
\hline $\mathrm{T} 12$ & $23(31.1)$ & $20(26.3)$ & \\
\hline LI & $21(28.4)$ & $32(42.1)$ & \\
\hline L2 & $21(28.4)$ & $19(25.0)$ & \\
\hline \multicolumn{4}{|l|}{ AO classification, n (\%) } \\
\hline Al & $24(32.4)$ & $21(27.6)$ & 0.896 \\
\hline A2 & $21(28.4)$ & $23(30.2)$ & \\
\hline A3 & $18(24.3)$ & $19(25.0)$ & \\
\hline A4 & II (I4.9) & $13(17.2)$ & \\
\hline \multicolumn{4}{|l|}{ Trauma mechanism, n (\%) } \\
\hline Fall from height & $53(7 \mid .6)$ & $25(32.9)$ & $<0.001$ \\
\hline Simple fall & $10(13.5)$ & $22(28.9)$ & \\
\hline In-car accident & $8(10.8)$ & $15(19.7)$ & \\
\hline Pedestrian accident & $3(4.1)$ & $14(18.3)$ & \\
\hline Extra-vertebral fracture, n (\%) & $17(23.0)$ & $20(26.3)$ & 0.635 \\
\hline
\end{tabular}

$(\mathrm{p}<0.00 \mathrm{I}, \mathrm{p}<0.00 \mathrm{I}$ and $\mathrm{p}<0.00 \mathrm{I}$, respectively). No significant difference was observed between the groups concerningpre-treatment VAS values $(p=0.709)$. Although the surgery group showed better improvement in VAS scores within the six months postoperatively, no significant difference was observed at the $24^{\text {th }}$-month evaluation (Fig. I). The $24^{\text {th }}$ month ODI, LKA and VHL values were significantly lower in the surgery group (Table 2). Also, the time to return to work was statistically significant in the surgery group $(p<0.001)$. When compared with the pre-treatment values, it was noteworthy

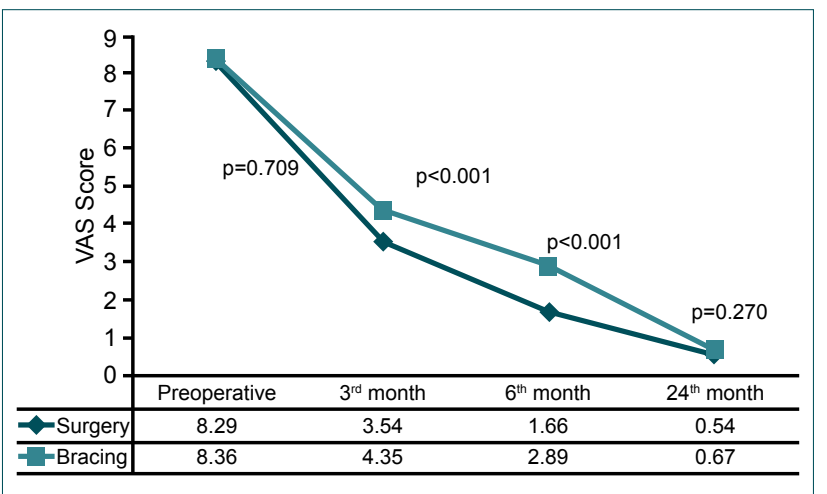

Figure 1. Preoperative and postoperative Visual Analog Scale (VAS) values of the groups. that the third-, sixth- and $24^{\text {th }}$ - month VHL increased in the brace group $(p<0.001)$.

\section{DISCUSSION}

There are four important findings that were obtained in the current study. First, the surgery group had significantly better functional outcomes within the six-month follow-up. Second, the surgery group showed better improvement in VAS scores at the $3^{\text {rd }}$ - and $6^{\text {th }}$-month postoperatively, but not the $24^{\text {th }}$-month. Third, the $3^{\text {rd }}-, 6^{\text {th }}$, and $24^{\text {th }}$-month LKA and $\mathrm{VHL}$ values were significantly lower in the surgery group. Lastly, the return to work was significantly earlier in the surgery group. TLICS has been suggested as a reliable classification for guidance in the treatment of acute thoracolumbar spinal trauma. ${ }^{[10]}$ However, the TLICS has no clear recommendation for guiding surgeons for the treatment of patients with a score of TLICS 4. ${ }^{[2]}$ This ambiguity arises from indeterminate imaging findings as to the integrity of PLC, whether disrupted or intact. Two systematic reviews about the treatment of patients in traumatic thoracolumbar fractures without neurological deficits have demonstrated that there is a lack of evidence providing a reliable answer to whether operative or conservative treatment is more effective. ${ }^{[6,11]}$ Therefore, the present study compared the clinical and ra- 
Table 2. Comparison of clinical and radiological outcomes of the patients in both groups

\begin{tabular}{|c|c|c|c|}
\hline & Surgery $(n=74)$ & Conservative $(n=76)$ & $\mathbf{p}$ \\
\hline & Mean $\pm S D$ & Mean $\pm S D$ & \\
\hline \multicolumn{4}{|l|}{ Clinical evaluation } \\
\hline ODI score & $19.89 \pm 9.9$ & $29.9 \pm 6.9$ & $<0.001$ \\
\hline \multicolumn{4}{|l|}{ VAS score } \\
\hline Pre-treatment & $8.29 \pm 1.3$ & $8.36 \pm 1.1$ & 0.709 \\
\hline $3^{\text {rd }}$ month & $3.54 \pm 1.1$ & $4.35 \pm 1.0$ & $<0.001$ \\
\hline $6^{\text {th }}$ month & $1.66 \pm 0.9$ & $2.89 \pm 0.9$ & $<0.001$ \\
\hline $24^{\text {th }}$ month & $0.54 \pm 0.6$ & $0.67 \pm 0.7$ & 0.270 \\
\hline Return to work (days) & $104.79 \pm 20.6$ & $|42.2| \pm 18.5$ & $<0.001$ \\
\hline \multicolumn{4}{|l|}{ Radiological evaluation } \\
\hline \multicolumn{4}{|l|}{ LKA (O) } \\
\hline Pre-treatment & $31.58 \pm 4.6$ & $32.89 \pm 5.6$ & 0.123 \\
\hline $3^{\text {rd }}$ month & $28.6 \pm 7.9$ & $33.8 I \pm 4.8$ & 0.020 \\
\hline $6^{\text {th }}$ month & $26.2 \pm 6.9$ & $34.5 \pm 2.6$ & 0.004 \\
\hline $24^{\text {th }}$ month & $20.56 \pm 10.77$ & $38.17 \pm 6.0$ & $<0.001$ \\
\hline \multicolumn{4}{|l|}{ Vertebra height loss (\%) } \\
\hline Pre-treatment & $60.24 \pm 8.6$ & $58.46 \pm 9.2$ & $<0.001$ \\
\hline $3^{\text {rd }}$ month & $21.98 \pm 5.3$ & $59.72 \pm 4.9$ & $<0.001$ \\
\hline $6^{\text {th }}$ month & $21.43 \pm 8.3$ & $61.27 \pm 7.1$ & $<0.001$ \\
\hline $24^{\text {th }}$ month & $20.21 \pm 3.2$ & $67.6 I \pm 8.7$ & $<0.001$ \\
\hline
\end{tabular}

ODI: Oswestry disability index; VAS: Visual Analog Scale; LKA: Local kyphosis angle; SD: Standard deviation. Statistically significant p values marked as bold.

diological outcomes of non-operative treatment and surgery in TLICS 4 patients.

The studies compared the surgical versus conservative treatment in TLICS 4 vertebra fractures in the literature have conflicting results. Siebenga et al. ${ }^{[2]}$ found better clinical and radiological outcomes in patients with $A O$ type $A$ fractures and treated surgically than conservatively after mean 4.3 years follow-up. Mohamadi et al. ${ }^{[3]}$ suggested using surgical treatment rather than conservative treatment due to significantly lower pain scores and shorter time to return to work in TLICS 4 fractures. Similar to our results, Shen et al. ${ }^{[13]}$ reported better improvement in pain scores for the surgical treatment compared to conservative treatment at an intermediate follow-up time; however, there was no difference at the latest follow-up. On the other hand, there is a conspicuous study highlighting the conservative treatment as a safe approach in TLICS 4 patients $(n=20)$ compared with TLICS $\leq 3$ patients $(n=38)$ treated conservatively. ${ }^{[14]}$ This study demonstrated that conservative treatment for TLICS 4 thoracolumbar fractures could be safely applied and the conservative treatment of cases scoring TLICS 4 is equally effective to those scoring $\leq 3$. Furthermore, Nataraj et al. ${ }^{[15]}$ found no significant difference in terms of ODI, VAS score and time to return to work in another study comparing surgically- and conservatively- treated patients during sixmonth follow-up. Compared with the previous studies, the sample size was relatively larger and the mean follow-up period was relatively longer in the present study. According to our results, time to return to work was significantly shorter in the surgery group compared with the bracing group and the surgery group showed better improvement in terms of ODI and VAS score. Although a better improvement was found at the $3^{\text {rd }}$ - and the $6^{\text {th }}$-month in VAS scores, the results were similar inthe $24^{\text {th }}$-month.

Another important issue that needs to be underscored in the treatment of stable vertebra fractures without neurological deficit is the kyphotic angle because the vertebral column becomes unstable as the kyphotic angle increases. ${ }^{[1,7,16]}$ In this context, the integrity of PLC has a critical role. ${ }^{[7,17]}$ Surgical treatment is indicated in case of persistent back pain and progressive kyphosis during the follow-up of relevant patients. ${ }^{[16]}$ In the current study, the surgery group had significantly lower LKA and VHL at the $3^{\text {rd }}$, $6^{\text {th }}$ - and $24^{\text {th }}$-month. Also, LKA and $\mathrm{VHL}$ in the surgical group tended to decrease towards the postoperative $24^{\text {th }}$-month, while the brace group tended to increase. The orthosis allows preventing gross trunk movements rather than preventing intervertebral movement, but reminds and helps the patient to keep the trunk in an up- 
right position. ${ }^{[1]}$ However, there has been a debate about the effectiveness of bracing in stable fractures. ${ }^{[18]}$ Bailey et al. ${ }^{[19]}$ concluded that using the brace in burst fractures with neurologically stable patients did not affect the outcome regarding pain control and function. In the current paper, similarly to Bailey's study, complete and incomplete burst fractures with neurologically stable patients did not show the differences regarding the clinical outcomes. Shamji et al. ${ }^{[20]}$ compared bracing with no-bracing groups in their randomized controlled trial whereby there was no difference regarding the VHL, kyphotic progression or clinical outcomes during the sixth months of the follow-up period. In the present study, a significant increase in kyphotic deformity in the bracing group at $3^{\text {rd }}$ - $6^{\text {th }}$ - and $24^{\text {th }}$-month was observed. This progression of kyphotic deformity may be due to indeterminate PLC injury and/or inadequate trunk stability due to the failure of the brace treatment. There are some limitations to the present study. The retrospective design and no randomization are the main limitations. Although the follow-up period (at least 24 months) is acceptable compared with the previous studies, it could be longer. Differences regarding the gender between the groups are another limitation. This could be attributed to that male patients might have consented to surgery more easily. However, a more homogenous group would be noteworthy.

\section{Conclusion}

The present study demonstrated that the surgical treatment for TLICS 4 patients with thoracolumbar fractures had better clinical and radiographic outcomes compared with the bracing at the $3^{\text {rd }}$-, $6^{\text {th }}$ - and $24^{\text {th }}$-month postoperatively. Although there was a better improvement in VAS pain scores in the surgery group within six months postoperatively, the groups showed similar results at the $24^{\text {th }}$-month evaluation. Moreover, it was shown that returning time to work of patients is shortened with surgery. As a result, our results suggest surgical treatment as the first and the appropriate choice in the management of TLICS 4 thoracolumbar vertebral fractures.

Ethics Committee Approval: All procedures performed in studies involving human participants were following the ethical standards of the institutional and/or national research committee and with the 1964 Helsinki declaration and its later amendments or comparable ethical standards.

Peer-review: Internally peer-reviewed.

Authorship Contributions: Concept: E.K., O.Ç.; Design: E.K., A.D.; Supervision: O.Ç., A.K.Ö.; Fundings: O.Ç., T.E.; Materials: E.K., O.Ç.; Data: E.K., A.K.Ö., T.E.; Analysis: T.Ö., A.D.; Literature search: E.K., A.D., O.Ç.; Writing: E.K.; Critical revision: A.D., E.K.

\section{Conflict of Interest: None declared.}

Financial Disclosure: The authors declared that this study has received no financial support.

\section{REFERENCES}

1. Joaquim AF, Patel AA, Schroeder GD, Vaccaro AR, A simplified treatment algorithm for treating thoracic and lumbar spine trauma. J Spinal Cord Med 2019;42:416-22. [CrossRef]

2. Schroeder GD, Harrop JS, Vaccaro AR. Thoracolumbar Trauma Classification. Neurosurg Clin N Am 2017;28:23-9. [CrossRef]

3. Mohamadi A, Googanian A, Ahmadi A, Kamali A. Comparison of surgical or nonsurgical treatment outcomes in patients with thoracolumbar fracture with Score 4 of TLICS: A randomized, single-blind, and singlecentral clinical trial. Medicine (Baltimore) 2018;97:e9842. [CrossRef]

4. Dodwad SN, Dodwad SJ, Wisneski R, Khan SN. Retrospective Analysis of Thoracolumbar Junction Injuries Using the Thoracolumbar Injury Severity and Classification Score, American Spinal Injury Association Class, Injury Severity Score, Age, Sex, and Length of Hospitalization. J Spinal Disord Tech 2015;28:E410-6. [CrossRef]

5. Joaquim AF, Ghizoni E, Tedeschi H, Batista UC, Patel AA. Clinical results of patients with thoracolumbar spine trauma treated according to the Thoracolumbar Injury Classification and Severity Score. J Neurosurg Spine 2014;20:562-7. [CrossRef]

6. van der Roer N, de Lange ES, Bakker FC, de Vet HC, van Tulder MW. Management of traumatic thoracolumbar fractures: a systematic review of the literature. Eur Spine J 2005;14:527-34. [CrossRef]

7. Radcliff K, Su BW, Kepler CK, Rubin T, Shimer AL, Rihn JA, et al. Correlation of posterior ligamentous complex injury and neurological injury to loss of vertebral body height, kyphosis, and canal compromise. Spine (Phila Pa 1976) 2012;37:1142-50. [CrossRef]

8. Yakut E, Düger T, Oksüz C, Yörükan S, Ureten K, Turan D, et al. Validation of the Turkish version of the Oswestry Disability Index for patients with low back pain. Spine (Phila Pa 1976) 2004;29:581-5; discussion: 585.

9. Price DD, McGrath PA, Rafii A, Buckingham B. The validation of visual analogue scales as ratio scale measures for chronic and experimental pain. Pain 1983;17:45-56. [CrossRef]

10. Joaquim AF, de Almeida Bastos DC, Jorge Torres HH, Patel AA. Thoracolumbar Injury Classification and Injury Severity Score System: A Literature Review of Its Safety. Global Spine J 2016;6:80-5. [CrossRef]

11. Thomas KC, Bailey CS, Dvorak MF, Kwon B, Fisher C. Comparison of operative and nonoperative treatment for thoracolumbar burst fractures in patients without neurological deficit: a systematic review. J Neurosurg Spine 2006;4:351-8. [CrossRef]

12. Siebenga J, Leferink VJ, Segers MJ, Elzinga MJ, Bakker FC, Haarman $\mathrm{HJ}$, et al. Treatment of traumatic thoracolumbar spine fractures: a multicenter prospective randomized study of operative versus nonsurgical treatment. Spine (Phila Pa 1976) 2006;31:2881-90. [CrossRef]

13. Shen WJ, Liu TJ, Shen YS. Nonoperative treatment versus posterior fixation for thoracolumbar junction burst fractures without neurologic deficit. Spine (Phila Pa 1976) 2001;26:1038-45. [CrossRef]

14. Pneumaticos SG, Karampinas PK, Triantafilopoulos G, Koufos S, Polyzois V, Vlamis J. Evaluation of TLICS for thoracolumbar fractures. Eur Spine J 2016;25:1123-7. [CrossRef]

15. Nataraj A, Jack AS, Ihsanullah I, Nomani S, Kortbeek F, Fox R. Outcomes in Thoracolumbar Burst Fractures With a Thoracolumbar Injury Classifcation Score (TLICS) of 4 Treated With Surgery Versus Initial Conservative Management. Clin Spine Surg 2018;31:E317-21. [CrossRef]

16. Hitchon PW, Abode-Iyamah K, Dahdaleh NS, Shaffrey C, Noeller J, $\mathrm{He} \mathrm{W}$, et al. Nonoperative Management in Neurologically Intact Thoracolumbar Burst Fractures: Clinical and Radiographic Outcomes. Spine (Phila Pa 1976) 2016;41:483-9. [CrossRef]

17. Khurana B, Sheehan SE, Sodickson A, Bono CM, Harris MB. Traumatic 
thoracolumbar spine injuries: what the spine surgeon wants to know. Radiographics 2013;33:2031-46. [CrossRef]

18. Joaquim AF, Patel AA. Thoracolumbar spine trauma: Evaluation and surgical decision-making. J Craniovertebr Junction Spine 2013;4:3-9.

19. Bailey CS, Dvorak MF, Thomas KC, Boyd MC, Paquett S, Kwon BK, et al. Comparison of thoracolumbosacral orthosis and no orthosis for the treatment of thoracolumbar burst fractures: interim analysis of a multicenter randomized clinical equivalence trial. J Neurosurg Spine 2009;11:295-303. [CrossRef]

20. Shamji MF, Roffey DM, Young DK, Reindl R, Wai EK. A pilot evaluation of the role of bracing in stable thoracolumbar burst fractures without neurological deficit. J Spinal Disord Tech 2014;27:370-5. [CrossRef]

\section{ORİIINAL ÇALIŞMA - ÖZET}

\section{Torakolomber yaralanma sinıflaması ve ciddiyet skoru $4($ TLICS $=4)$ olan torakolomber vertebra kırıklarının yönetimi: Cerrahi mi, konservatif tedavi mi?}

\section{Dr. Evren Karaali, ${ }^{1}$ Dr. Osman Çiloğlu, ${ }^{1}$ Dr. Altuğ Duramaz, ${ }^{2}$ Dr. Aslıhan Kuşvuran Özkan, ${ }^{3}$ Dr. Timur Ekiz ${ }^{4}$}

${ }^{1}$ Adana Şehir Hastanesi, Ortopedi ve Travmatoloji Kliniği, Adana

Bakırköy Dr. Sadi Konuk Eğitim ve Araştırma Hastanesi, Ortopedi ve Travmatoloji Kliniği, İstanbul

${ }^{3}$ Özülkü Tıp Merkezi, Fizik Tedavi ve Rehabilitasyon Kliniği, Adana

${ }^{4}$ İstanbul Gedik Üniversitesi Sağlık Bilimleri Fakültesi, Fizik Tedavi ve Rehabilitasyon Anabilim Dalı, İstanbul

AMAÇ: Torakolomber yaralanma sınıflaması ve ciddiyet skoru 4 (TLICS $=4$ ) olan nörolojik intakt torakolomber vertebra kırıklı hastalarda cerrahi tedavi ve korse tedavisinin klinik ve radyografik sonuçlarının karşılaştııılması amaçlandı.

GEREÇ VE YÖNTEM: Travmatik torakolomber kırık (TI I-L2), TLICS 4 skoru ve en az 24 ay takip edilen hastalar alındı. Hastalar cerrahi ve korse gruplarına ayrıldı. Gruplar klinik ve demografik özellikler, lokal kifoz açıları (LKA), vertebra yükseklik kaybı yüzdesi (VYK), Oswestry Engellilik İndeksi (ODI), Visual Analog Skala (VAS) ve işe geri dönme süresi açısından karşılaştıııldı.

BULGULAR: Cerrahi grubunda 74 hasta (7I erkek, 3 kadın), korse grubunda 76 hasta (58 erkek, 18 kadın) vardı. Cerrahi grupta ameliyat sonrası ilk altı ay içinde VAS skorlarında daha iyi olsa da 24. ayda gruplar arasında anlamlı bir fark gözlenmedi (sırasıyla, $p<0.00$ I ve $p=0.270$ ). ODI, LKA ve VYK cerrahi grubunda anlamlı olarak düşüktü (sırasıyla, $p<0.001$, $p<0.001$ ve $p<0.00$ I). İşe geri dönüş süresi ameliyat grubunda anlamlı olarak daha kısa idi $(p<0.00 I)$.

TARTIŞMA: Torakolomber kırıkları olan nörolojik olarak intakt TLICS 4 hastaların cerrahi tedavisinin, korseye göre daha iyi klinik ve radyografik sonuçları olduğunu saptandı. Ayrıca, hastaların işe dönüş sürelerinin cerrahi tedavi ile kısaltıldığı gösterildi. TLıCS 4 torakolomber vertebral kırıkların tedavisinde cerrahi tedavi ilk ve uygun seçenek olarak görünmektedir.

Anahtar sözcükler: Cerrahi tedavi, klinik ve radyolojik sonuçlar; spinal korse; TLICS; torakolomber kırıklar.

Ulus Travma Acil Cerrahi Derg 2020;26(5):805-810 doi: 10.14744/tjtes.2020.30524 